\title{
Southern Redcedar and Southern Magnolia Wood Chip Mulches for Weed Suppression in Containerized Woody Ornamentals
}

\author{
James Ferguson, Bala Rathinasabapathi ${ }^{1}$, and Clinton Warren
}

ADDITIONAL INDEX wORDs. Juniperus silicicola, Magnolia grandiflora, large crabgrass, Digitaria sanguinalis, nursery crops, organic production, redroot pigweed, Amaranthus retroflexus, weed control

SUMMARY. Wood chip mulches from southern redcedar (Juniperus silicicola) and southern magnolia (Magnolia grandiflora) were evaluated for their effectiveness in weed control in nursery containers. In greenhouse tests, southern redcedar and southern magnolia wood chip mulches significantly inhibited the germination of redroot pigweed (Amaranthus retroflexus) and large crabgrass (Digitaria sanguinalis). In a field trial, nursery containers with 'Carolina Beauty' crape myrtle plants (Lagerstroemia indica) were sown with large crabgrass and redroot pigweed seeds, mulched with southern redcedar or southern magnolia wood chips, and compared with plants without mulch and plants treated with a mixture of isoxaben and trifluralin (Snapshot). Wood chips from both southern redcedar and southern magnolia were as effective as a mixture of isoxaben and trifluralin in suppressing weed growth in nursery containers. The wood chip mulches had no inhibitory effect on the growth of crape myrtle plants. In a similar, longer-term field trial using containerized dogwood (Cornus florida) plants sown with large crabgrass and redroot pigweed, the southern redcedar wood chip mulch was most effective in weed suppression when used in combination with a low dose of the chemical herbicide.

$\mathrm{W}$ Ceed control in container nursery plants is a major production problem, especially for perennial plants grown in field nurseries over time (Altland, 2003 ). Weeds compete with the nursery plants for available resources, harbor pests and diseases, and downgrade crop quality. Although preventive weed control measures, including exclusion, groundcovers, and cultivation, are used in adjacent land, chemical weed control, especially with granular preemergent herbicides, is widely used in production areas (Norcini and Stamps, 1994).

Preemergent herbicides such as isoxaben (Gallery DF; Dow Agrosciences, Indianapolis, IN), napropamide (Devrinol; United Phosphorus, Trenton, NJ), prodiamine (Barricade; Syngenta, Wilmington, DE), s-

Horticultural Sciences Department, University of Florida, 2247 Fifield Hall, Gainesville, FL 326110690

Financial support in the form of a grant to J.F. and B.R from the Florida Nursery Growers and Landscape Association Endowed Research Fund is gratefully acknowledged. We thank Grandiflora Nursery, Gainesville, FL, for crape myrtle and dogwood plants used in this study.

${ }^{1}$ Corresponding author. E-mail: brath@ufl.edu. metolachlor (Pennant; Syngenta), and oxyfluorfen (Goal; Dow Agrosciences) are commonly used for weed control in containerized nurseries. However, nonchemical control methods have also been actively researched and used. Chong (2003) used discs made of semirigid plastic, fabrics, polyfoam, pressed peatmoss, and insulated blankets that provided both winter freeze protection and weed control. Organic mulches like chipped and shredded tree bark, pelletized shredded newspaper, and rice hulls have reduced weed growth in container nurseries (Mathers and Ozkan, 2001), but can also reduce nitrogen availability because of high carbon:nitrogen ratios (Billeaud and Zajicek, 1989). Herbicide-treated
Douglas Fir (Pseudotsuga menziesii) bark nuggets provided a $150 \%$ increase in weed control efficacy over preemergent herbicides and reduced nursery plant phytotoxicity (Mathers, 2003).

Research on the use of natural products for weed management has focused primarily on agronomic and horticultural field crops with little application to containerized plant production (Weston, 2005). However, wood chips and leaf mulches from several woody perennials, including southern redcedar and southern magnolia, may contain water-soluble natural products with phytotoxic activities and they could therefore be used for suppressing weeds in horticultural production systems (Rathinasabapathi et al., 2005). The objective of this study was to evaluate the suitability of weed-suppressive wood chip mulches for weed control in nursery container plants.

\section{Materials and methods}

WOOD AND PLANT MATERIAL. Freshly cut limbs, $\approx 5 \mathrm{~cm}$ in diameter, and leaves from the current season's growth of mature southern redcedar, oriental arborvitae (Thuja orientalis), leyland cypress (Juniperus leylandii), and southern magnolia were chipped into 5 to $10-\mathrm{mm}$-thick and 10 to $20-\mathrm{mm}$-long fragments using an Asplundh Whisper Wood Chipper (Asplundh Tree Expert Co., Chalfont, PA) and used in this study. This plant material was stored in a cool, dry area under shade and used in greenhouse and field tests within 2 weeks after they were cut. Seeds of large crabgrass and redroot pigweed were purchased from Valley Seed Service (Fresno, CA).

LetTuce bioassay. Preparation of water leachates of wood chips and a lettuce (Latuca sativa) bioassay for weed-suppressive activity were described previously (Ferguson

\begin{tabular}{llll}
\hline $\begin{array}{l}\text { Units } \\
\begin{array}{l}\text { To convert U.S. to SI, } \\
\text { multiply by }\end{array}\end{array}$ & U.S. unit & SI unit & $\begin{array}{l}\text { To convert SI to U.S., } \\
\text { multiply by }\end{array}$ \\
\hline 29.5735 & $\mathrm{fl} \mathrm{oz}$ & $\mathrm{mL}$ & 0.0338 \\
3.7854 & gal & $\mathrm{L}$ & 0.2642 \\
2.54 & inch(es) & $\mathrm{cm}$ & 0.3937 \\
25.4 & inch(es) & $\mathrm{mm}$ & 0.0394 \\
1.1209 & lb/acre & $\mathrm{kg} \cdot \mathrm{ha}^{-1}$ & 0.8922 \\
1 & micron & $\mu \mathrm{m}$ & 1 \\
28.3495 & $\mathrm{Oz}$ & $\mathrm{g}$ & 0.0353 \\
$\left({ }^{\circ} \mathrm{F}-32\right) \div 1.8$ & ${ }^{\circ} \mathrm{F}$ & ${ }^{\circ} \mathrm{C}$ & $\left(1.8 \times{ }^{\circ} \mathrm{C}\right)+32$ \\
& & & \\
\hline
\end{tabular}


et al., 2004). Briefly, leachates after incubation of wood chips in water (5 g fresh weight in $50 \mathrm{~mL}$ water) for $24 \mathrm{~h}$ at $37^{\circ} \mathrm{C}$ was filter-sterilized using a $0.2-\mu \mathrm{m}$ nitrocellulose filter unit. Seeds of 'Green Ice' lettuce were surface-sterilized by rinsing in $10 \%$ $(\mathrm{v} / \mathrm{v})$ commercial bleach and thoroughly washed in sterile, distilled water. An autoclaved Whatman No. 2 filter paper circle was placed inside a sterile disposable petri dish $(100 \times$ $15 \mathrm{~mm}$ ) and the paper was wetted by adding either $3 \mathrm{~mL}$ sterile water (control) or $3 \mathrm{~mL}$ of the test leachates. Surface-sterilized seeds (20 per plate) were placed on the wet filter paper discs and the petri dishes were sealed using parafilm. The plates were incubated at $24^{\circ} \mathrm{C}$ under a light bench with an 11 -h light cycle of $12 \mu \mathrm{mol} \cdot \mathrm{m}^{-2} \cdot \mathrm{s}^{-1}$ photosynthetic photon flux. The lengths of radicles were measured after $72 \mathrm{~h}$. The experiment was done twice with 20 seeds for each treatment.

EFFECT OF MULCHES ON WEED SEED GERMINATION. Square plastic pots $(5 \times 5 \times 2$ inches $)$ with drain holes were half-filled with vermiculite. Hairy crabgrass or redroot pigweed seeds ( 50 seeds per pot) were placed between two Whatman No. 2 paper circles and the filter paper-seed double layer was placed on the vermiculite layer. The paper double layer with weed seeds was covered with a $1-\mathrm{cm}$ layer of vermiculite. Pots containing weed seeds were topped with a 1.5-inch-thick layer of either southern magnolia or southern redcedar wood chip mulches or 3-cm-thick layer of vermiculite (control) with 10 replicates per treatment. The pots were placed in a greenhouse in Gainesville, FL, and irrigated daily for 1 week. Maximum and minimum temperatures during the experimental period were 40 and $30{ }^{\circ} \mathrm{C}$, respectively. At the end of 1 week, the mulches were removed and weed seed germination was recorded as radicle and hypocotyl emergence and compared with germination in the control vermiculite mulch.

C O N T A I N E R N U R S R Y EXPERIMENTS ON WEED SUPPRESSION. Two field experiments were conducted between 1 Apr. and 15 Aug. 2005 and a third experiment between 1 June and 15 Aug. 2005 in a simulated container nursery on the University of Florida campus in Gainesville.
Crape myrtle. Uniform, vegetatively-propagated crape myrtle plants trimmed to $45-\mathrm{cm}$ height were potted in 5-gal plastic containers in a commercial potting medium (MetroMix 200; Scotts-Sierra, Marysville, $\mathrm{OH}$ ) and placed on a black plastic fabric in full sun. Metro Mix was chosen for this and the subsequent experiments instead of the more commonly used pine bark-based propagation media to avoid potential effects from water soluble compounds from the pine bark confounding the effect of wood chip mulches. Weed seeds of large crabgrass and redroot pigweed (300 seeds of each species per container) were sown around all crape myrtle plants, one weed species to one side of the container and the other to the opposite, and covered with potting medium. One day after sowing, containers were mulched with a 1.5inch-thick layer of southern redcedar or southern magnolia wood chip mulches. For comparison, a mixture of $0.5 \%$ (by weight) isoxaben and $2.0 \%$ (by weight) trifluralin (Snapshot; Dow AgroScience) was then applied by hand to other containers at the recommended rate of $1 \mathrm{~g}$ formulation per container, which is comparable to a rate of $2.5 \mathrm{lb} /$ acre formulation. Control plants received no mulch or herbicide treatment. Each treatment had six replicates arranged in a completely randomized design. The plants were watered by hand to container capacity $(\approx 1$ gal water per container) twice per week or as needed. One month after the start of the experiment, $14 \mathrm{~g}$ of a controlled-release fertilizer $(12 \mathrm{~N}-$ $2.6 \mathrm{P}-4.9 \mathrm{~K})$ was applied to each plant. On 15 May 2005 (45 d), the weeds were harvested, placed in plastic bags, and weighed immediately and the heights of the crape myrtle plants were measured. Total weeds for each treatment were harvested and weighed instead of weeds for each replicate of each treatment being harvested separately. Accordingly, this experiment was repeated from 1 June to 15 Aug. 2005 (76 d) with weed weight and plant height for each replicate of each treatment taken separately and analyzed.

Dogwood. A longer field experiment was conducted between 15 Mar. 2006 and 15 Aug. 2006 (153 d) to determine if reduced herbicide rates plus southern redcedar mulch would be as effective as the recommended herbicide rate in suppressing weeds. Uniform, flowering dogwood plants trimmed to $45 \mathrm{~cm}$ high were potted in 5-gal plastic containers in a commercial potting medium (MetroMix 200; Scotts-Sierra) and placed on a black plastic fabric in full sun. Weed seeds of large crabgrass and redroot pigweed (300 seeds of each species per container) were sown around all dogwood plants, one weed species to one side of the container and the other to the opposite, and covered with potting medium. One day after sowing, containerized plants were mulched with a 1.5 -inch-thick layer of southern redcedar wood chip mulch. Others were left unmulched or treated with either 0.4 or $0.8 \mathrm{~g}$ of Snapshot, lower than the recommended rate of 1 g per plant, plus southern redcedar mulch. Treatments were replicated six times and arranged in a completely randomized design. The plants were watered by hand to container capacity $(\approx 1$ gal water per container) twice per week or as needed. On 16 May 2006, $14 \mathrm{~g}$ of a controlled-release fertilizer (12N$2.6 \mathrm{P}-4.9 \mathrm{~K})$ was applied to each plant. On 15 Aug. 2006, the weeds in each container were harvested, placed in plastic bags, and weighed immediately and the height of the dogwood plants measured.

Statistical treatment. Analyses of quantitative data were performed using SAS (version 9.1; SAS Institute, Cary, NC). After analysis of variance, Duncan's multiple range test was used for mean separation.

\section{Results and discussion}

Using a lettuce bioassay, our previous studies indicated that southern redcedar and southern magnolia wood chips contained watersoluble, plant-suppressive chemicals (Rathinasabapathi et al., 2005). To confirm this and to test wood chips from two other species related to southern redcedar, a laboratory lettuce germination bioassay was used to evaluate the leachates from oriental arborvitae, southern redcedar, southern magnolia, and leyland cypress and compared with autoclaved water. Except for the leachate from leyland cypress, those from the other three species significantly reduced lettuce seed germination (Fig. 1), confirming 
the results from our previous study (Rathinasabapathi et al., 2005). Although oriental arborvitae was very effective in the bioassay, wood chip mulches from this source were not tested further because of nonavailability in sufficient quantity.

Leachates from southern redcedar and oriental arborvitae leacheate reduced lettuce radicle growth, but leyland cypress leacheate did not differ from the control, suggesting that members of the Cupressaceae family could differ in their weed-suppressive potential and more species could therefore be profiled for bioactive natural products.

Greenhouse trials showed that wood chip mulches from southern redcedar and southern magnolia significantly inhibited germination of large crabgrass (Fig. 2A) and redroot pigweed (Fig. 2B) compared with the vermiculite mulch control. Red root pigweed was more severely suppressed by southern redcedar and southern magnolia mulches than large crabgrass. Greater suppression of germination of red root pigweed compared with large crabgrass suggested that dicots may be more susceptible than monocots (Fig. 2). Observations on the growth of these weed species in separate and the same containers suggested that redroot pigweed and large crabgrass did not exhibit allelopathic inhibition on each other. Further studies are

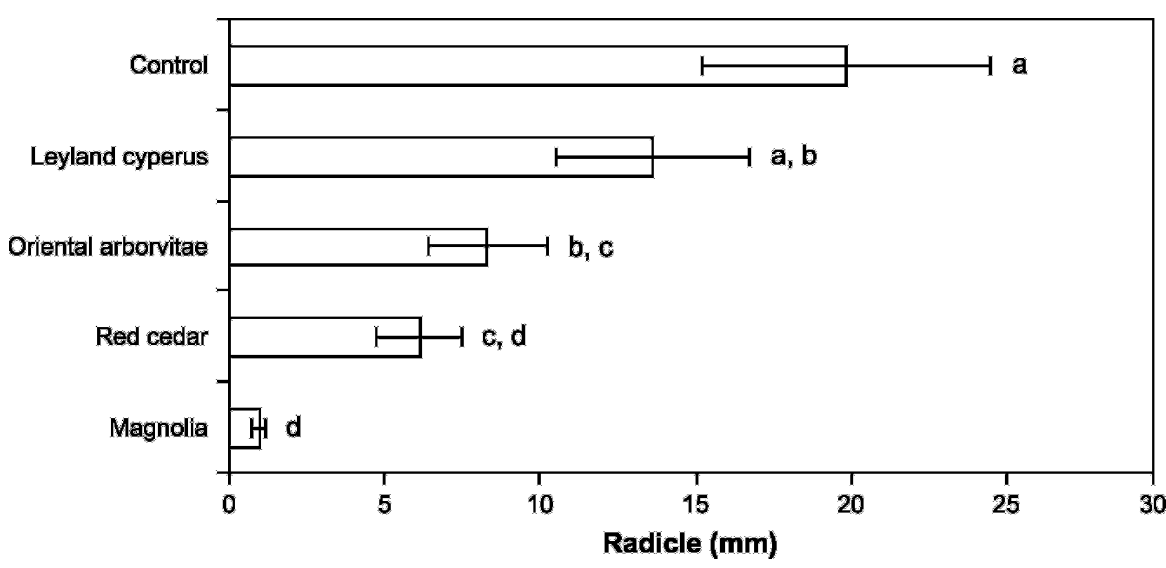

Fig. 1. Reduction of radicle growth of lettuce by water leachates of wood chips from leyland cypress, oriental arborvitae, southern redcedar, and southern magnolia compared with water control. Bars represent mean and SE for 19 replicates per treatment. Bars followed by the same letters are not significantly different at $P=0.05$ ( $1 \mathrm{~mm}=0.0394$ inch $)$.

required to test the effect of weedsuppressive mulches on a variety of weed species, especially those commonly prevalent in nursery containers such as bittercress (Cardamine hirsuta), common groundsel (Senecio vulgaris), and prickly lettuce (Lactuca serriola).

In the 2005 crape myrtle trial, both southern redcedar and southern magnolia mulches suppressed weed growth as effectively as the herbicide control (Fig. 3A). Crape myrtle plant height at the end of the trial was not significantly affected (Fig. 3B). In these field trials, although both redroot pigweed and large crabgrass were sown in each container and both germinated, redroot pigweed did not grow further and survived well in containers treated with mulches. This suggested that redroot pigweed was suppressed more by the mulch than large crabgrass, similar to what was observed in the greenhouse experiments. Weed biomass and crape myrtle plant height results compiled by treatment and not replicate per treatment from the 1 Apr. to 15 May 2005 field experiment (data not shown) were similar to results from the 1 June to 15 Aug. 2005 experiment (Fig. 3).

In the 153-d-long dogwood field trial in 2006, fresh weight of weeds taken from containerized dogwood plants receiving no treatment was significantly greater than that of dogwood plants grown on mulch alone or mulch plus 0.4 or $0.8 \mathrm{~g}$ herbicide treatment (Fig. 4). In this trial, combining a lower herbicide
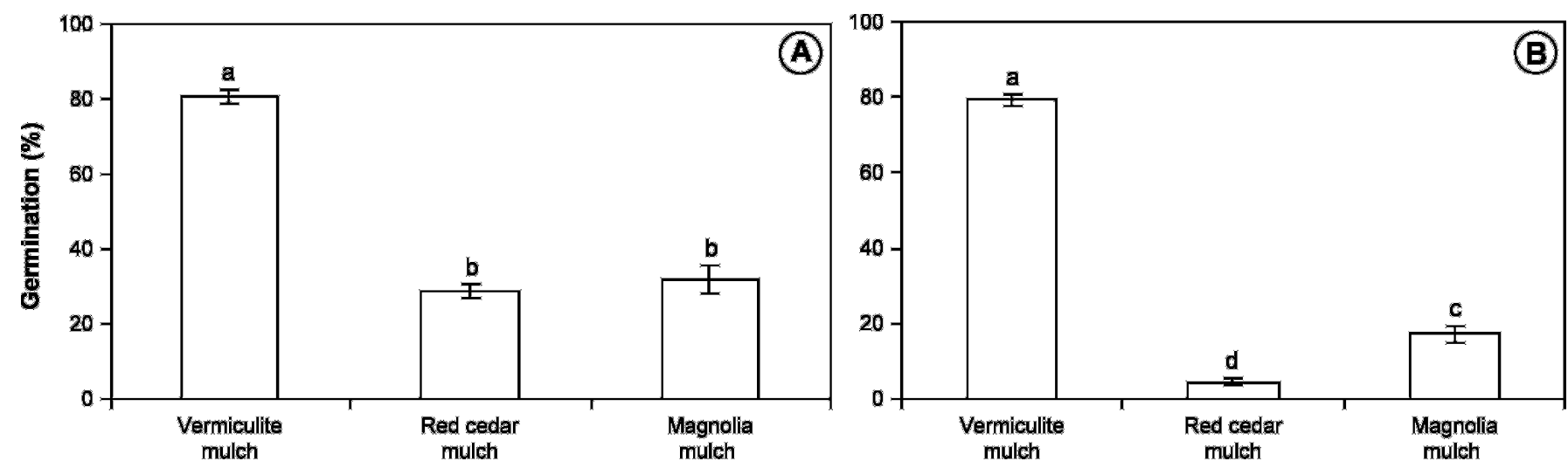

Fig. 2. Germination of (A) hairy crabgrass and (B) redroot pigweed affected by southern redcedar and southern magnolia mulches compared with vermiculite mulch in a greenhouse experiment. Data from all six treatments (shown in A and B) were analyzed together using the analysis of variance. Means marked with the same letter were not significantly different from each other at $P=0.05$. The error bars represent the SE with $n=10$ per treatment. 

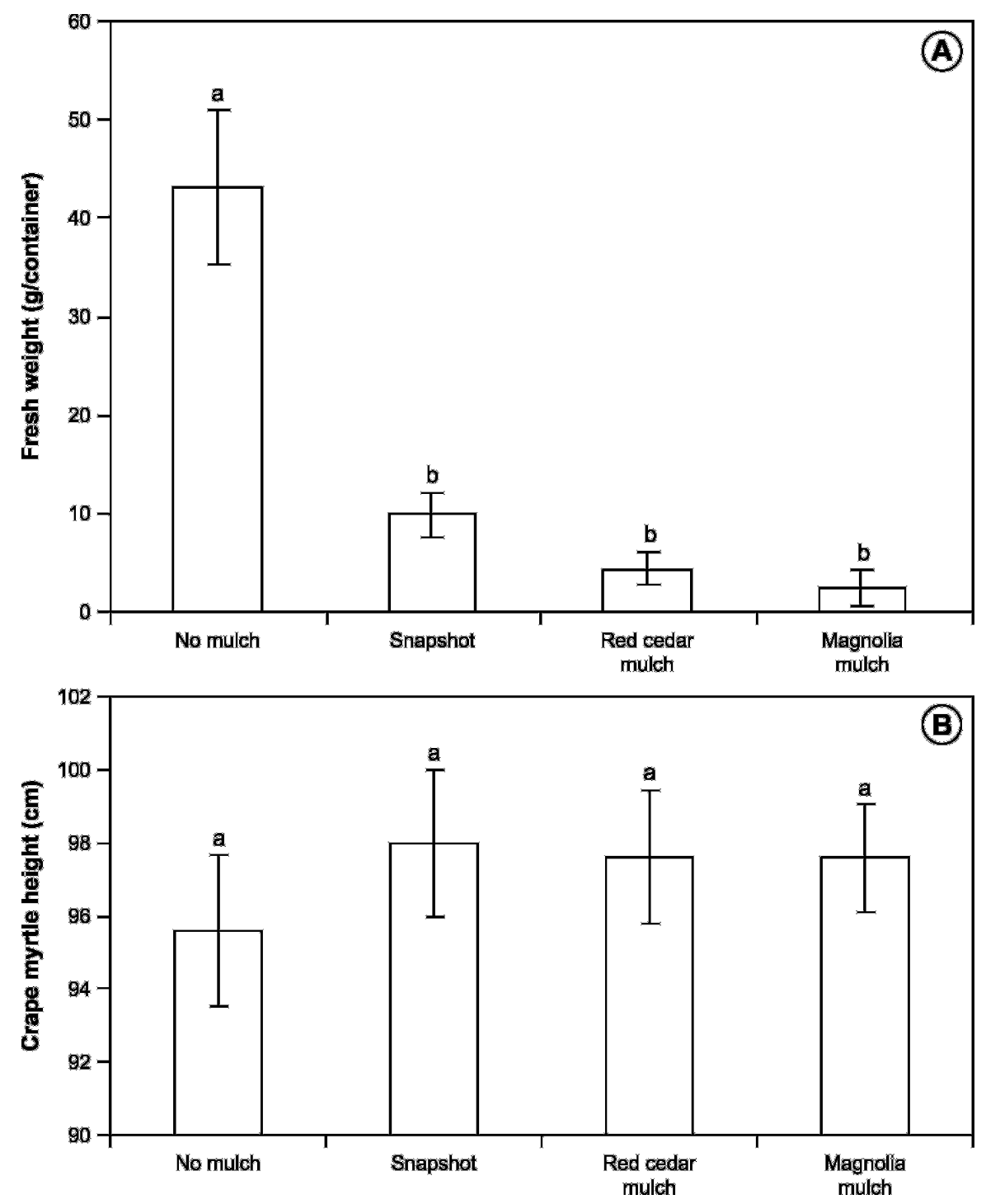

Fig. 3. Effect of southern redcedar and southern magnolia mulches on weed suppression and crape myrtle plant growth. (A) Weed growth and (B) crape myrtle plant growth were recorded at the end of the field experiment with the following treatments. No mulch $=$ control with no mulch or chemical herbicide; Snapshot $=$ treatment with a mixture of $0.5 \%$ (by weight) isoxaben and $2.0 \%$ (by weight) trifluralin (Snapshot; Dow AgroScience, Indianapolis, IN) at the rate of $1 \mathrm{~g}$ per container; Southern redcedar mulch and Southern magnolia mulch $=1.5$-inch-thick $(3.81 \mathrm{~cm})$ wood chip mulch from indicated species. The bars represent the means and $S E$ for $n=6$. Means marked with the same letter were not significantly different from each other at $P=0.05(1 \mathrm{~g}=0.0353 \mathrm{oz}, 1 \mathrm{~cm}=0.3937$ inch $)$.

rate than recommended $(0.8$ versus $1.0 \mathrm{~g}$ per container) plus mulch reduced weed growth the most (Fig. 4). Dogwood plant height at the end of the trial was not significantly affected by treatment (data not shown).

In the 2005 field trials, both southern redcedar and southern magnolia mulches suppressed weeds in containerized plants as effectively as a preemergent herbicide treatment.
Large crabgrass was again more competitive than redroot pigweed under the conditions of this study.

The 2006 field trial suggested that lower-than-recommended herbicide rates combined with mulch and mulch alone treatments could suppress weed growth over $\approx 5$ months.

Weed control was not $100 \%$, even with the preemergent herbicide treatment. Outdoor experiments were conducted in a field area that was mowed regularly but subject to high summer temperatures and heavy summer rains. The recorded rainfall during the periods of 1 June 2005 to 15 Aug. 2005 and 15 Mar. 2006 to 15 Aug. 2006 were 15.49 and 14.23 inches, respectively (Florida Automated Weather Network, 2007). These conditions promote the loss of herbicides or other herbicidal chemicals from the containers by leaching as has been documented for chemical herbicides (Norcini and Stamps, 1994). Future studies therefore should examine the effect of loss of allelochemicals from biomulches and their potential effects on dormant weed seeds.

One of the important requirements for the use of weed-suppressive biomulches in nursery containers is that the mulch should suppress the weeds but not the crop plant growth. Based on measurements of growth of the host plant crape myrtle (Fig. 3) and dogwood (data not shown), the mulches did not have any negative effects on the host plant. Our results demonstrate that wood chip mulches from southern redcedar and southern magnolia can be used for weed suppression in container-grown crape myrtle and that southern redcedar mulches can be used for weed suppression in container-grown dogwood. Although field experiments were conducted from 45 to $153 \mathrm{~d}$ under Florida conditions, these results are valuable first observations on the use of weed-suppressive biomulches.

Wood chip mulches in nursery containers may be attractive alternatives to chemical weed control, especially because 38 million metric tons of urban tree residue are produced annually in the United States (National Research Council, 2000). Many European nurseries routinely practice topping containers with wood chip mulch and a mechanical bark spreader is available (Linthorst, 2006). However, limited local supply of specific tree species like southern magnolia and southern redcedar could restrict application of these mulches to situations in which synthetic herbicides cannot be used (e.g., organic production). Research reported here also suggests that isolation of herbicidal compounds from select 


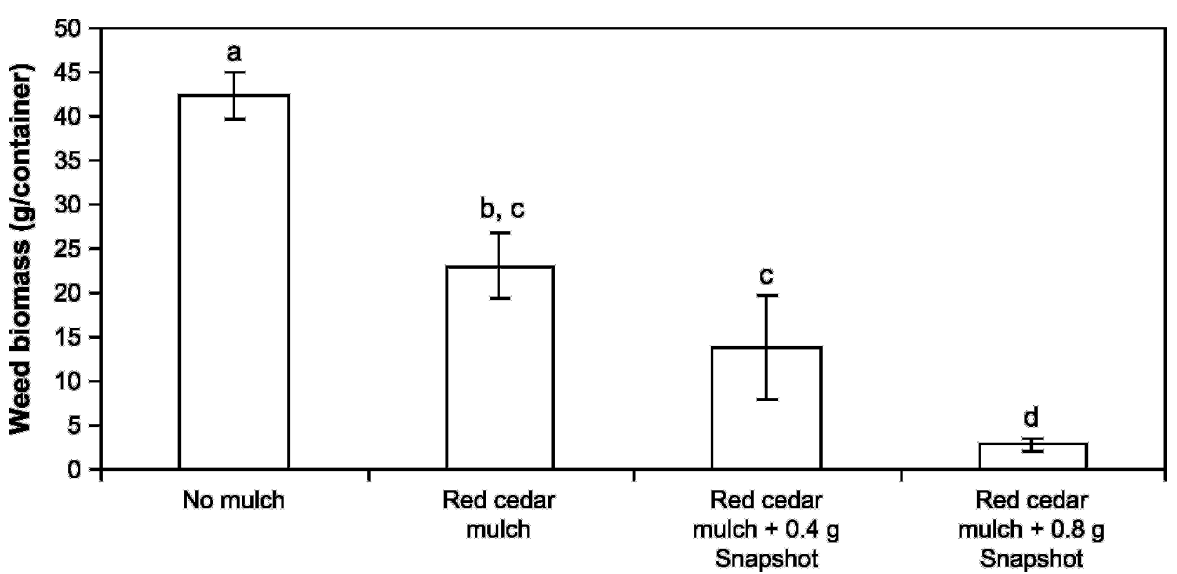

Fig. 4. Effect of southern redcedar mulch plus herbicide on weed suppression and plant growth. Weed growth per container was recorded for the following treatments at the end of the field trial. No mulch $=$ control with no mulch or chemical herbicide; $S$. redcedar mulch $=1.5$-inch-thick $(3.81 \mathrm{~cm})$ layer of southern redcedar mulch; $S$. redcedar mulch $+0.4 \mathrm{~g}$ Snapshot $=$ a mixture of $0.5 \%$ (by weight) isoxaben and $2.0 \%$ (by weight) trifluralin (Snapshot; Dow AgroScience,

Indianapolis, IN) at the rate of $0.4 \mathrm{~g}$ per container with 1.5-inch-thick layer of southern redcedar mulch; $S$. redcedar mulch $+0.8 \mathrm{~g}$ Snapshot $=$ Snapshot at the rate of $0.8 \mathrm{~g}$ per container with 1.5 -inch-thick layer of southern redcedar mulch. The bars represent the means and $\mathrm{SE}$ for $\mathbf{n}=6$. Means marked with the same letter were not significantly different from each other at $P=0.05(1 \mathrm{~g}=0.0353 \mathrm{oz})$

species could potentially be useful as bioherbicides or templates for novel synthetic herbicides.

\section{Literature cited}

Altland, J. 2003. Weed control in container crops: A guide to effective weed management through preventive measures. Oregon State Univ. Ext. Serv. Publ. EM 8823.
Billeaud, L.A. and J.M. Zajicek. 1989 Influence of mulches on weed control, soil $\mathrm{pH}$, soil nitrogen content and growth of Ligustrum japonicum. J. Environ. Hort. 7:155-157.

Chong, C. 2003. Experiences with weed discs and other nonchemical alternatives for container weed control. Hort Technology 13:23-27.

Elmore, C.L. and C.A. Wilen. 2005. Floriculture and ornamental nurseries:
Container nurseries. 21 Nov. 2006. <http://axp.ipm.ucdavis.edu/PMG/ r280701211.html>;

Ferguson, J., B. Rathinasabapathi, and M. Gal. 2004. A method to screen weedsuppressing allelochemicals in Florida biomass. Proc. Florida State Hort. Soc. 117:231-233.

Florida Automated Weather Network. 2007. 5 Sept. 2007. <http://fawn.ifas. ufl.edu>.

Linthorst, B.V. 2006. Welkom op barkstrooier.nl. 21 Nov. 2006. <http://www. barkstrooier.nl>;

Mathers, H. and E. Ozkan. 2001. Herbicide treated mulches. Nursery Mgt. Production 17:61-6466.

Mathers, H.M. 2003. Novel methods of weed control in containers. HortTechnology 13:28-34.

National Research Council. 2000. Biobased industrial products: Priorities for research and commercialization. National Academy Press, Washington, DC.

Norcini, J.G. and R.H. Stamps. 1994. Container nursery weed control. Univ. Florida Coop. Ext. Serv. Circ. 678.

Rathinasabapathi, B., J. Ferguson, and M. Gal. 2005. Evaluation of allelopathic potential of wood chips for weed suppression in horticultural production systems. HortScience 40:711713.

Weston, L.A. 2005. History and current trends in the use of allelopathy for weed management. Hort Technology 15:529534. 